\title{
Erratum to: Environmental characteristics of tropical coral reef-seagrass dominated lagoons (Lakshadweep, India) and implications to resilience to climate change
}

\author{
E. P. Nobi • P. K. Dinesh Kumar
}

Published online: 13 June 2014

(C) Springer-Verlag Berlin Heidelberg 2014

\section{Erratum to: Environ Earth Sci}

DOI 10.1007/s12665-013-3020-9

In the original article, the value of $\mathrm{pH}(7.6-8.6)$ and the subsequent sentence given in the Abstract are an accidental typographical error and not representing the actual result of the study. It must read as "The $\mathrm{pH}$ of sediment was relatively high in the coral reef compared to the seagrass area, indicating that the coral reefs of this area are not currently under the threat of ocean acidification".

The online version of the original article can be found under doi:10.1007/s12665-013-3020-9.

E. P. Nobi $(\bowtie)$

Ministry of Environment and Forests, Paryavaran Bhavan, C.G.O. Complex, Lodhi Road, New Delhi 110 003, India

e-mail: nobiep2007@gmail.com

P. K. Dinesh Kumar

CSIR-National Institute of Oceanography, Regional Centre,

Dr. Salim Ali Road, Kochi 682 018, India

e-mail: dineshku@nio.org 